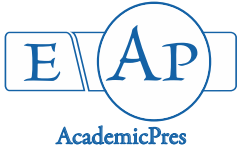

Douaer N et al. (2021)

Notulae Scientia Biologicae 13(1):10804

DOI: $10.15835 / \mathrm{nsb} 13110804$

Research Article

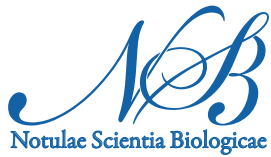

\title{
The effect of municipal sewage sludge on properties physicochemical and microbial agricultural soil
}

\author{
Naima DOUAER ${ }^{1 *}$, Abdelkader DOUAOUI², Madjid MEHAIGUENE ${ }^{1}$, \\ Mohamed ZOUIDI ${ }^{3}$, Wiem HAMZA ${ }^{4}$ \\ ${ }^{1}$ Djilali Bounaama University of Khemis Miliana, Department of Biology, Agricultural Production and Sustainable Development of \\ Natural Resources, Khemis Miliana, Algeria; bionaima2014@gmail.com (*corresponding author); mehaiguenemadjid@yahoo.fr \\ ${ }^{2}$ University Center of Tipaza, Laboratory Management and Valorization of Agriculture and Aquatic Ecosystems (LMVAAE), \\ Algeria; aekdouaoui@gmail.com \\ ${ }^{3}$ University of Saida, Water Resources and Environment Laboratory, Saida, Algeria; zouidibiologie20@gmail.com \\ ${ }^{4}$ University of Sfax, Laboratory of Water-Energy-Environment (LR3E), National School of Engineers of Sfax, BPW 3038, Sfax, \\ Tunisia; hamzawiem@gmail.com
}

\begin{abstract}
The organic matter content of sludge can improve the physical, chemical and biological properties of the soil ensuring better cultivation and good agricultural productivity. The objective of this study is to evaluate the effect of sewage sludge on the main physicochemical and biological properties of the soil. The sludge was spread in an agricultural field in Ain defla (Algeria) cultivated with a tomato crop ('Panikra') in four treatments: $(\mathrm{T})$ : soil without sewage sludge and without mineral fertilization, $(\mathrm{B})$ : soil with sewage sludge, $(\mathrm{E})$ : soil with mineral fertilization, $(B+E)$ : soil with sewage sludge and mineral fertilization. For this, several physical, chemical and microbiological properties were analyzed on the residual sludge used and the soils collected in the studied plots. The results show that the sludge used does not exhibit any toxicity and that the treatment with the sewage sludge with the fertilizer used on the agricultural soil forms a better compost for improving the physicochemical quality of the soil compared to the other treatments. The application of sewage sludge also can accelerate microbial activity by increasing the number of bacteria, fungi and azotobacter.
\end{abstract}

Keywords: fertilization; organic matter; major elements; soil properties; tomato

\section{Introduction}

The beginning of the $21^{\text {st }}$ century has been marked by notable developments that continue to transform world agriculture and rural economies due to the continued growth of the world population, the demands to feed and improve the quality of life of this population so we are particularly concerned. Internationally interested in developments in agriculture that could directly address growing concerns about future food security, productivity and sustainability $(\mathrm{FAO}, 2015)$. The recovery of urban sludge in agriculture is a major sector in wastewater management. Each year, $70 \%$ of sewage sludge is recovered by composting or agricultural spreading, and more than $80 \%$ in the sanitation services managed by water companies. Although sewage sludge

Received: 19 Aug 2020. Received in revised form: 05 Feb 2021. Accepted: 18 Feb 2021. Published online: 23 Feb 2021.

From Volume 13, Issue 1, 2021, Notulae Scientia Biologicae journal will use article numbers in place of the traditional method of continuous pagination through the volume. 
is considered as waste, it is nevertheless of agronomic interest because of its richness in organic matter, nitrogen, phosphorus and a favourable carbon / nitrogen ratio (Becerra-Castro et al., 2015).

Sewage sludge is composed of organic compounds, macronutrients, a wide range of micronutrients, nonessential trace metals, organic micropollutants and microorganisms (Kulling et al., 2001). The land application technique, as fertilizing resource, is one of the methods considered to be very effective and efficient. Sludge may be applied to agriculture lands, forest, disturbed land (Tchobanoglous and Burton, 2003). This method has the following advantages: harness important quantities of nutrients - organic matter, nitrogen, phosphorus, potassium, trace elements, reduced chemical fertilizers consumption, uses organic matter mineralization and the decontamination capacity of soil (Mosoarca and Negrea, 2012). The study of the state of purification in Algeria and more particularly in western Algeria has shown that our 156 purification stations annually produce significant quantities of sludge estimated at around 225,000 tonnes of dry matter (Sahnoun, 2019).

The use of sludge has a beneficial effect on the improvement of soil fertility; it contributes to the dynamic growth of the content of organic substances, which are rapidly transformed into soil humus. This is particularly important for degraded soils, as well as light soils, easily permeable, the physicochemical fertility of which by the sewage sludge is radically improved by contributing to increased agricultural productivity. In addition, it was found that the beneficial effect of sludge fertilization is visible only in the second and third year of sludge application (Antolín et al., 2005; Fernández et al., 2009) However, it has been shown that sewage sludge application at recommended rates increased microbial activity in soil and tied up the heavy metals making them unavailable to plant and soil (Sastre et al., 1996). Sewage sludge contains pathogenic bacteria, viruses and protozoa along with other parasitic helminths, which can give rise potential health hazards to human, animals and plants. Salmonella and Taenia, were identified as the greatest concern and risk to health from microbes in sewage sludge applied to land (World Health Organization, 1981.)

The objective of this study was to determine the effect of sewage sludge on the quality of agricultural soils and their effectiveness as a compost for the restoration of the physicochemical and biological properties of soils cultivated with tomato (Panikra) in a possibility of recovery of residual sludge and wastewater from the Ain Defla province WWTP and the suitability of tomato cultivation in the soil spread by the sludge by performing different analyzes according to the types of treatment used on the soil.

\section{Materials and Methods}

This study was performed out in an open area in the agricultural domain of SAADI Djilali in Arib Ain defla Algeria. There were 12 plots distributed over 3 blocks, each plot of $9 \mathrm{~m}^{2}(3 \mathrm{~m} \times 3 \mathrm{~m})$, these plots were divided into three rows by $1 \mathrm{~m}$ buffer zone and amended with either $3 \mathrm{~kg} / \mathrm{m}^{2}$ sewage sludge (Soulignac, 2000). The experimental design includes four treatments with three repetitions: T: soil without Sewage sludge and without mineral fertilization. B: soil with Sewage sludge. E: soil with mineral fertilization. B + E: soil with sewage sludge and mineral fertilization. The quantities of sewage sludge for the treatment $B$ and $B+E$ are equal to $3 \mathrm{~kg} / \mathrm{m}^{2}$. The composition of NPK fertilizer of treatment $\mathrm{E}$ and $\mathrm{B}+\mathrm{E}$ was 130 units of N / ha; 120 units of $\mathrm{P} / \mathrm{ha}$ and 150 units of $\mathrm{K} / \mathrm{ha}$. The field experimental plots were set up in a randomized block design as shown in Figure 1.

\section{Soil analysis}

Physicochemical analysis

Soil samples before and after harvesting were collected from each site in all plots from a depth of $20 \mathrm{~cm}$ (Zouidi et al., 2019). The samples were air dried, sieved through 2-mm sieve and kept in plastic bags. Texture evaluation was performed as described by Robinson Khon; total nitrogen content was determined by the Kjedhal method, Electrical Conductivity (EC) and $\mathrm{pH}$ were measured using $\mathrm{pH}$ and EC electrodes (JENWAY $3510 \mathrm{pH}$ metre; AD $331 \mathrm{EC}$ metre), water content was expressed by weight as the ratio of the mass between 
wet and dry samples. The criterion for a dry sample was a weight of sample after drying in oven at temperature between 100 and $110{ }^{\circ} \mathrm{C}$. Organic matter was determined by calcination at $550^{\circ} \mathrm{C}$ for $16 \mathrm{~h}$, Total Organic Carbon (TOC) was determined by oxidation sulfochromique. Major elements contents were determined by $\mathrm{X}$-ray fluorescence in oxidized form on a solid solution sample called lozenge. This procedure is related to the practical instrumental method of basic soil analysis by X-ray fluorescence spectrophotometry and concentrations of heavy metals and microbiological parameters were determined. Soil had texture clay loam; alkaline $\mathrm{pH}$ and low organic matter content as summarized in Table 1.

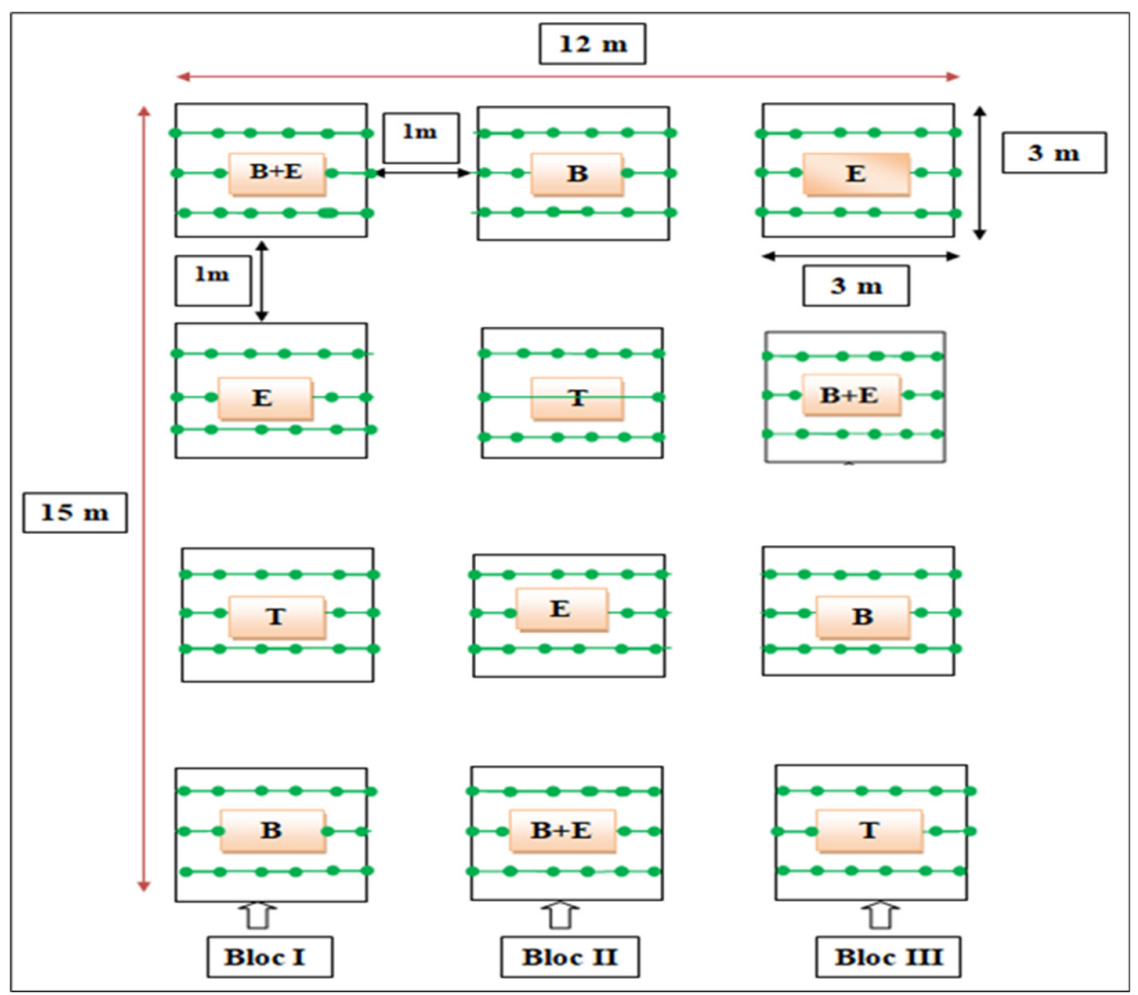

Figure 1. Representative schema of experimental field

Table 1. Physicochemical parameters of soil before application of sewage sludge

\begin{tabular}{|c|c|c|c|c|c|c|c|c|c|c|}
\hline Parameters & $\begin{array}{c}\text { Water } \\
\text { content } \\
(\mathrm{ww}) \%\end{array}$ & $\mathrm{pH}$ & $\begin{array}{c}\mathrm{EC} \\
\mathrm{mS} / \mathrm{cm}\end{array}$ & $\begin{array}{c}\mathrm{O} . \mathrm{M} \\
(\%)\end{array}$ & $\begin{array}{c}\mathrm{TOC} \\
\%\end{array}$ & $\begin{array}{c}\mathrm{Na} \\
\mathrm{meq} / \\
100 \mathrm{~g}\end{array}$ & $\begin{array}{c}\mathrm{Ca} \\
\mathrm{meq} / \\
100 \mathrm{~g}\end{array}$ & $\begin{array}{c}\mathrm{Mg} \\
\mathrm{meq} / \\
100 \mathrm{~g}\end{array}$ & $\begin{array}{c}\mathrm{K} \\
\mathrm{meq} / \\
100 \mathrm{~g}\end{array}$ & $\begin{array}{c}\mathrm{P} \\
\mathrm{meq} / \\
100 \mathrm{~g}\end{array}$ \\
\hline Concentrations & 4.69 & 8.4 & 0.13 & 1.36 & 0.25 & 0.12 & 7.17 & 1.52 & 2.15 & 37.88 \\
\hline
\end{tabular}

\section{Microbiological analysis}

The soil sample was mixed, and a suspension of $1 \mathrm{~g}$ (dry weight equivalent) in $10 \mathrm{ml}$ of sterile water was prepared. One ml of the soil suspension was then diluted serially (ten-fold) and used in the estimation of aerobic heterotrophic bacterial and fungal populations by standard spread-plate dilution method described by Seeley and Van Demark (1981), in triplicate.

The fungi are grown on the nutrient OGA medium with decimal dilutions of the soil at the rate of 3 drops of each dilution $\left(10^{-1}\right.$ to $\left.10^{-6}\right)$ or $0.2 \mathrm{ml}$ are placed on each box and incubation was at $28^{\circ} \mathrm{C}$ for 7 days. (Bedjadj, 2011). The dilutions of the soil have been added on the nutrient agar favouring the cultivation of azotobacters; the colonies developed after incubation at $28^{\circ} \mathrm{C}$ for 7 days (Zouidi, 2019). Bacterial counts were in the order of $10^{5}-10^{7} \mathrm{cfu} / \mathrm{g}$ of soil, while fungal counts were in the order of $10^{3}-10^{5} \mathrm{cfu} / \mathrm{g}$ of soil. 


\section{Collection of sludge}

The sludge for the experiment was taken on $12 / 03 / 2017$, from wastewater treatment located in the territory of Ain Defla province (Algeria). The sludge was collected from randomly on drying beds (on both ends of the beds and at the center) where the mixed sludge subjected to dehydration. The principle is based on filtration and evaporation of the natural sludge in the drying zone in order to reduce the water content of the sludge for the physicochemical and microbiological analysis of this sludge.

\section{Physicochemical parameters of sewage}

The physicochemical parameters of the sludge are recorded in Table 2, Based on the measurement of $\mathrm{pH}$ and electrical conductivity, the sewage sludge is neutral $(7.21)$ and salty $(3.81 \mathrm{~ms} / \mathrm{cm})$ and significantly higher organic matter content, carbon content and key nutrients. Mean concentrations of heavy metals were present at low concentrations, not exceeding allowable levels according to the AFNOR NA 17671 norm for the trace element contents of the sludge sample. The different elements are organized in the following order: $\mathrm{Zn}>\mathrm{Co}>\mathrm{Pb}>\mathrm{Cr}>\mathrm{Ni}>\mathrm{Cd}>\mathrm{Hg}$.

Table 2. Physicochemical parameters of sewage sludge used in the experiment

\begin{tabular}{|c|c|}
\hline Physicochemical parameters & Sewage sludge \\
\hline $\mathrm{pH}$ & 7.21 \\
\hline Electrical conductivity EC $(\mathrm{ms} / \mathrm{cm})$ & 3.81 \\
\hline Water content $($ ww)\% & 56.1 \\
\hline Volatile matter $(\mathrm{M} . \mathrm{V})$ & 39.91 \\
\hline Organic Matter $(\mathrm{O} . \mathrm{M}) \%$ & 76.54 \\
\hline Carbon $\%$ & 15.17 \\
\hline Azote $(\mathrm{g} / \mathrm{kg})$ & 38 \\
\hline Chrome $(\mathrm{mg} / \mathrm{kg})$ & 48 \\
\hline Nickel $(\mathrm{mg} / \mathrm{kg})$ & 09 \\
\hline Copper $(\mathrm{mg} / \mathrm{kg})$ & 105 \\
\hline Cadmium $(\mathrm{mg} / \mathrm{kg})$ & 01 \\
\hline Zinc $(\mathrm{mg} / \mathrm{kg})$ & 474 \\
\hline Plomb $(\mathrm{mg} / \mathrm{kg})$ & 75 \\
\hline Mercury $(\mathrm{mg} / \mathrm{kg})$ & 0.1 \\
\hline
\end{tabular}

\section{Sludge microbiological analysis}

Microbiological properties sewage sludge used in the experiment was determined in the hygiene laboratory of Tipasa province and in the laboratory to the production of culture nutrients IMEN LAB; The NPP method was used to determine the total coliforms, fecal coliforms and fecal streptococci.

Table 3. Microbiological parameters of sewage sludge used in the experiment

\begin{tabular}{|c|c|c|c|c|c|c|c|c|c|c|c|c|c|c|c|c|}
\hline \multirow{2}{*}{\begin{tabular}{|c|}
$\begin{array}{c}\text { Sludge } \\
\text { samples }\end{array}$ \\
$\mathrm{S}$ \\
\end{tabular}} & \multicolumn{2}{|c|}{$\begin{array}{c}\text { Coliform } \\
\text { total }\end{array}$} & \multicolumn{2}{|c|}{$\begin{array}{c}\text { Coliform } \\
\text { fecal }\end{array}$} & \multicolumn{2}{|c|}{ Clostridium } & \multicolumn{2}{|c|}{$\begin{array}{c}\text { Streptococcus } \\
\text { fecal }\end{array}$} & \multicolumn{2}{|c|}{ Salmonella } & \multicolumn{2}{|c|}{ Vibrio } & \multicolumn{2}{|c|}{$\begin{array}{l}\text { Helminth } \\
\text { egg }\end{array}$} & \multicolumn{2}{|c|}{$\begin{array}{c}\text { Staphylococcus } \\
\text { aureus }\end{array}$} \\
\hline & $\mathrm{R}$ & $\mathrm{N}$ & $\mathrm{R}$ & $\mathrm{N}$ & $\mathrm{R}$ & $\mathrm{N}$ & $\mathrm{R}$ & $\mathrm{N}$ & $\mathrm{R}$ & $\mathrm{N}$ & $\mathrm{R}$ & $\mathrm{N}$ & $\mathrm{R}$ & $\mathrm{N}$ & $\mathrm{R}$ & $\mathrm{N}$ \\
\hline S1 & 160 & $*$ & 26 & $2 \times 10^{6}$ & IND & - & 92 & - & - & $<8-10 \mathrm{~g}$ MS & - & - & + & $<3-10 \mathrm{~g}$ MS & + & - \\
\hline S2 & 160 & $*$ & 40 & $2 \times 10^{6}$ & IND & - & 160 & - & - & $<8-10 \mathrm{~g}$ MS & - & - & + & $<3-10 \mathrm{~g}$ MS & + & - \\
\hline S3 & +240 & $*$ & 60 & $2 \times 10^{6}$ & IND & - & 160 & - & - & $<8-10 \mathrm{~g}$ MS & - & - & + & $<3-10 \mathrm{~g}$ MS & + & - \\
\hline S4 & 160 & $*$ & 23 & $2 \times 10^{6}$ & IND & - & 160 & - & - & $<8-10 \mathrm{~g}$ MS & - & - & + & $<3-10 \mathrm{~g}$ MS & + & - \\
\hline
\end{tabular}

S: Sample, R: Results, ${ }^{*}$ Norms OMS, N: norms, + Indicate presence, - Indicate absence

According to the table, the studied sludge contains a significant number of pathogens such as total coliforms, fecal coliforms, clostridia, faecal streptococcus, Staphylococcus aureus and helminth eggs. We note that sample $S 3$ is the sample most loaded with pathogenic microorganisms. The results also show that the 
residual sludge used in the spreading tests complied with the French norm NF U 44-095 (JO 26 March 2004) and the Tunisian norms NT 106-20 (2002) (Raïs et al., 2016). According to Duchene (1990), the very specific living conditions (temperature, humidity, richness of the environment) necessary for the good development of pathogenic germs are not encountered during the biological treatment of wastewater, neither during the treatment of sludge nor of the spreading which means that most of the germs are totally destroyed.

\section{Results and Discussion}

\section{Soil control}

Table 4 showed that the soil texture was determined as clay loam, it composed of $38.4 \%$ silt, $31.6 \%$ clay and $30 \%$ sand. The soil samples are characterized by a low organic matter content and an alkaline $\mathrm{pH}(8.36) \mathrm{a}$ slight increase in $\mathrm{pH}$ was recorded after harvest (8.52), the statistical study shows that this difference in $\mathrm{pH}$ was and weakly significant $(\mathrm{p}<0.05)$.

The statistical analysis of variance indicated that electrical conductivity (EC) was strongly significant $(\mathrm{p}<0.001)$, the values ranged between 0.13 and $0.48 \mathrm{~ms} / \mathrm{cm}$.

The determination of the total organic matter (O. M) and carbon contents revealed low values before the application of sewage sludge ( $1.26 \%$ for O. $\mathrm{M}$ and $0.32 \%$ for carbon) and after harvest $(1,28 \%$ for O. M: $0.30 \%$ for carbon), statistical analysis of variance indicated that this difference is not significant. A slight increase was recorded after the application of these sewage sludge. The determination of the total major element content before harvest revealed low values for $\mathrm{P}, \mathrm{Mg}$ and $\mathrm{Na}$ and high values for $\mathrm{K}$ and $\mathrm{Ca}$, then an increase in the values of $\mathrm{P}$ and $\mathrm{Na}$ observed during the experiment as we shown in Table 4.

Table 4. Mean values of physicochemical parameters of soil control before and after harvesting

\begin{tabular}{|c|c|c|c|c|}
\hline Treatment T & $\begin{array}{c}\text { Before application of } \\
\text { sewage sludge }\end{array}$ & $\begin{array}{c}\text { After 2-month application of } \\
\text { sewage sludge }\end{array}$ & $\begin{array}{c}\text { After } \\
\text { harvesting }\end{array}$ & $\begin{array}{c}\text { Standard } \\
\text { deviation }\end{array}$ \\
\hline $\mathrm{pH}$ & 8.36 & 8.53 & 8.52 & 0.147 \\
\hline $\mathrm{EC}(\mathrm{ms} / \mathrm{cm})$ & 0.13 & 0.17 & 0.48 & 0.071 \\
\hline Silt $(\%)$ & 38.40 & 26.40 & 27.20 & 6.272 \\
\hline Clay (\%) & 31.60 & 30.80 & 36.40 & 3.917 \\
\hline Sand $(\%)$ & 30 & 41.90 & 37.20 & 8.125 \\
\hline $\mathrm{O} . \mathrm{M}(\%)$ & 1.26 & 1.45 & 1.28 & 0.672 \\
\hline $\mathrm{C}(\%)$ & 0.32 & 0.93 & 0.30 & 0.689 \\
\hline $\mathrm{K}(\mathrm{mg} / \mathrm{l})$ & 106.4 & 12.34 & 9.36 & 30.762 \\
\hline $\mathrm{Na}(\mathrm{mg} / \mathrm{l})$ & 2.59 & 2.33 & 4.42 & 0.457 \\
\hline $\mathrm{Mg}(\mathrm{mg} / \mathrm{l})$ & 18.73 & 13.84 & 12.82 & 1.273 \\
\hline $\mathrm{Ca}(\mathrm{mg} / \mathrm{l})$ & 146.62 & 170.5 & 132.71 & 25.816 \\
\hline $\mathrm{P}(\mathrm{mg} / \mathrm{l})$ & 1.90 & 1.79 & 2.30 & 0.601 \\
\hline
\end{tabular}

\section{Soil with sewage sludge}

Based in table 5, it has been observed an increase of soil $\mathrm{pH}$ and $\mathrm{EC}$ for sites which were amended with sewage sludge but they were low than the sites which were not amended with sewage sludge (Tsadilas et al., 2002). Mihalache et al. (2007), reported also an increase in soil pH in soils treated with sewage sludge. The changes in soil $\mathrm{pH}$ have been correlated with the calcium carbonate content of sludge (Sommers, 1977).

ANOVA analysis of $\mathrm{pH}$ variance shows that the change in soil $\mathrm{pH}$ is weakly significant $(\mathrm{p}<0.05)$, but it is highly significant $(\mathrm{p}<0.001)$ for CE electrical conductivity, according to Benmouffok et al. (2005), soils treated with residual sludge tend to have a neutral $\mathrm{pH}$ and become enriched in phosphorus and organic matter. The spreading of sewage sludge can induce a salinity effect in agricultural soils (Morisot and Tournier, 1986), the organic matter in the sites which have been amended by the sewage sludge is $1.34 \%$, which is higher than 
organic matter and carbon in soil samples that were not modified by sewage sludge. The determination of the total content of major elements before harvest shows an increase in $\mathrm{Na}$ values; $\mathrm{Ca}$ and $\mathrm{P}$; and the values decrease for $\mathrm{K}$ and $\mathrm{Mg}$. Therefore, statistical analysis of total major element content (ANOVA) in soil samples amended by sewage sludge shows a significant difference $(\mathrm{p}<0.05)$ as summarized in Table 5.

Table 5. Mean values of physicochemical parameters of soil with sewage sludge before application of sewage sludge and after harvesting

\begin{tabular}{|c|c|c|c|c|}
\hline Treatment B & $\begin{array}{c}\text { Before application of } \\
\text { sewage sludge }\end{array}$ & $\begin{array}{c}\text { After 2-month application of } \\
\text { sewage sludge }\end{array}$ & $\begin{array}{c}\text { After } \\
\text { harvesting }\end{array}$ & $\begin{array}{c}\text { Standard } \\
\text { deviation }\end{array}$ \\
\hline $\mathrm{pH}$ & 8.42 & 8.45 & 8.45 & 0.067 \\
\hline $\mathrm{EC}(\mathrm{ms} / \mathrm{cm})$ & 0.12 & 0.13 & 0.51 & 0.112 \\
\hline Silt $(\%)$ & 38.70 & 25.20 & 27.20 & 6.239 \\
\hline Clay $(\%)$ & 27.90 & 31.60 & 34.80 & 5.865 \\
\hline Sand $(\%)$ & 34.10 & 41.60 & 37.20 & 9.761 \\
\hline $\mathrm{O} . \mathrm{M}(\%)$ & 1.39 & 0.92 & 1.34 & 0.475 \\
\hline $\mathrm{C}(\%)$ & 0.16 & 1.34 & 0.36 & 1.706 \\
\hline $\mathrm{K}(\mathrm{mg} / \mathrm{l})$ & 73.9 & 11.89 & 8.97 & 38.270 \\
\hline $\mathrm{Na}(\mathrm{mg} / \mathrm{l})$ & 2.87 & 1.84 & 5.48 & 0.736 \\
\hline $\mathrm{Mg}(\mathrm{mg} / \mathrm{l})$ & 17.79 & 14.4 & 13.7 & 1.496 \\
\hline $\mathrm{Ca}(\mathrm{mg} / \mathrm{l})$ & 141.65 & 178.3 & 135.17 & 24.087 \\
\hline $\mathrm{P}(\mathrm{mg} / \mathrm{l})$ & 1.78 & 1.68 & 2.65 & 0.612 \\
\hline
\end{tabular}

\section{Soil with fertilizer}

In this case the values of $\mathrm{pH}$ and Electrical conductivity EC varied significantly with NPK fertilizer as indicated in table 6. Analysis of ANOVA for the O.M in the sites which were amended by NPK fertilizer (P $<0.001)$ demonstrated lowest values than O.M in soil amended by sewage sludge, these results prove good fertilizing and soil improvement qualities of sludge.

As shown in Table 6, the average organic carbon contents in the soil samples amended with NPK fertilizer are lower compared to the soil samples amended with sewage sludge. This observation is consistent with the results of Singh and Agrawal (2011) and Mi et al. (2016) which showed that the application of organic fertilizers leads to an increase in organic carbon values compared to NPK fertilizers. It has been observed too an increase of the $\mathrm{Na}$ average and decrease of $\mathrm{K} ; \mathrm{Mg}$; $\mathrm{Ca}$; $\mathrm{P}$ average.

Table 6. Mean values of physicochemical parameters of soil with fertilizer before fertilization and after harvesting

\begin{tabular}{|c|c|c|c|c|}
\hline Treatment E & $\begin{array}{c}\text { Before application of } \\
\text { sewage sludge }\end{array}$ & $\begin{array}{c}\text { After 2-month application of } \\
\text { sewage sludge }\end{array}$ & $\begin{array}{c}\text { After } \\
\text { harvesting }\end{array}$ & $\begin{array}{c}\text { Standard } \\
\text { deviation }\end{array}$ \\
\hline $\mathrm{pH}$ & 8.40 & 8.47 & 8.46 & 0.062 \\
\hline $\mathrm{EC}(\mathrm{ms} / \mathrm{cm})$ & 0.13 & 0.13 & 0.56 & 0.080 \\
\hline Silt $(\%)$ & 38 & 30.80 & 28 & 7.327 \\
\hline Clay $(\%)$ & 30.40 & 31.60 & 36.80 & 5.158 \\
\hline Sand $(\%)$ & 30.40 & 37.60 & 34.80 & 8.671 \\
\hline $\mathrm{O} . \mathrm{M}(\%)$ & 1.32 & 0.94 & 0.97 & 0.166 \\
\hline $\mathrm{C}(\%)$ & 0.22 & 0.35 & 0.24 & 0.207 \\
\hline $\mathrm{K}(\mathrm{mg} / \mathrm{l})$ & 90.4 & 10.82 & 9.05 & 33.110 \\
\hline $\mathrm{Na}(\mathrm{mg} / \mathrm{l})$ & 2.62 & 2.12 & 4.89 & 0.738 \\
\hline $\mathrm{Mg}(\mathrm{mg} / \mathrm{l})$ & 18.34 & 13.79 & 12.43 & 0.842 \\
\hline $\mathrm{Ca}(\mathrm{mg} / \mathrm{l})$ & 140.83 & 144.3 & 133.21 & 34.355 \\
\hline $\mathrm{P}(\mathrm{mg} / \mathrm{l})$ & 2.03 & 1.59 & 1.90 & 0.394 \\
\hline
\end{tabular}




\section{Soil with sewage sludge and fertilizer}

Table 7 noted an increase in soil $\mathrm{pH}$ and electrical conductivity EC. So, $\mathrm{pH}$ increases from 7.81 units before application of sewage sludge and NPK fertilizer till 8.46 units after harvesting, and the values of EC ranged between 0.12 and $0.76 \mathrm{~ms} / \mathrm{cm}$. The amount of O.M in the sites which were amended with sewage sludge and NPK fertilizer is $2.63 \%$, which is higher than organic matter to all treatments. Soil samples with sewage sludge and fertilizer show a higher TOC value than all the other treatments; compared with the soil samples amended by NPK fertilizer; the soil samples amended by sewage sludge and the soil control., the average TOC is $3.25 \%$ after harvesting.

The determination of the total content of major elements before harvesting shows increase values for $\mathrm{Na}, \mathrm{Mg}$ and $\mathrm{P}$; and decrease values for $\mathrm{K}$ and $\mathrm{Ca}$. The results showed that the $\mathrm{pH}$, electrical conductivity $\mathrm{EC}$, TOC, organic matter, and total content of major elements $(\mathrm{Na}, \mathrm{Mg}, \mathrm{P})$ increased when the soil was amended with sewage sludge and fertilizer compared to all treatments.

This experiment showed that sewage sludge and fertilizer create good environment for physicochemical parameters of soil as compared to all the treatments, so the organization of the different treatments in the following order: $\mathrm{EE}+\mathrm{B}>\mathrm{EB}>\mathrm{EE}>\mathrm{ET}$ according to their efficiency.

Table 7. Mean values of physicochemical parameters of soil with sewage sludge and fertilizer before application of sewage sludge and after harvesting.

\begin{tabular}{|c|c|c|c|c|}
\hline $\begin{array}{c}\text { Treatment } \\
\text { E+B }\end{array}$ & $\begin{array}{c}\text { Before application of } \\
\text { sewage sludge }\end{array}$ & $\begin{array}{c}\text { After 2-month application } \\
\text { of sewage sludge }\end{array}$ & $\begin{array}{c}\text { After } \\
\text { harvesting }\end{array}$ & $\begin{array}{c}\text { Standard } \\
\text { deviation }\end{array}$ \\
\hline $\mathrm{pH}$ & 7.81 & 8.46 & 8.46 & 1.124 \\
\hline $\mathrm{EC}(\mathrm{ms} / \mathrm{cm})$ & 0.12 & 0.14 & 0.76 & 0.198 \\
\hline Silt $(\%)$ & 38.40 & 25.20 & 28 & 6.992 \\
\hline Clay $(\%)$ & 29.20 & 31.20 & 33.20 & 5.952 \\
\hline Sand $(\%)$ & 31.60 & 40.80 & 37.60 & 9.072 \\
\hline $\mathrm{O} . \mathrm{M}(\%)$ & 1.30 & 1.03 & 2.63 & 1.261 \\
\hline $\mathrm{C}(\%)$ & 0.28 & 2.12 & 3.25 & 3.875 \\
\hline $\mathrm{K}(\mathrm{mg} / \mathrm{l})$ & 101.6 & 11.26 & 9.31 & 36.549 \\
\hline $\mathrm{Na}(\mathrm{mg} / \mathrm{l})$ & 2.64 & 2.14 & 5.53 & 0.722 \\
\hline $\mathrm{Mg}(\mathrm{mg} / \mathrm{l})$ & 18.39 & 13.72 & 18.39 & 1.886 \\
\hline $\mathrm{Ca}(\mathrm{mg} / \mathrm{l})$ & 143.51 & 181.9 & 136.76 & 28.152 \\
\hline $\mathrm{P}(\mathrm{mg} / \mathrm{l})$ & 1.85 & 1.60 & 3.49 & 1.598 \\
\hline
\end{tabular}

\section{Microbiological analysis}

In the count of the microflora we have compared the bacteria, fungi and azotobacters in the control soil and soil with the sewage sludge in the 3 blocs.

\section{The total bacterial counts (TBC)}

The mean total bacterial counts (TBC) of soil sample before application of sewage sludge ranged between $10.40 \times 10^{4} \mathrm{UFC} / \mathrm{g}$ s.s and $54.54 \times 10^{4} \mathrm{UFC} / \mathrm{g}$ s.s. The values of total bacterial counts (TBC) were at $15.50 \times 10^{4} \mathrm{UFC} / \mathrm{g}$ s.s and $75.59 \times 10^{4} \mathrm{UFC} / \mathrm{g}$ s.s after application of sewage sludge as shown in Figure 2. Although highest counts were observed in soil sample bloc I, and lowest count was observed in soil sample bloc III. We observed that the bacteria were the most microorganism's dominant in soil, this predominance of bacteria could be attributed to the ubiquity of bacteria who can colonize different media and they can be activated for great areas of temperature, acidity, alkalinity, pressure and salinity (Dommergues, 1962).

The effect of acidity of the soil, when the acidity of soil is higher, when the microbial biomass is low. Bacteria are more favoured by environments close to neutrality (Boullard and Morceau, 1962). 


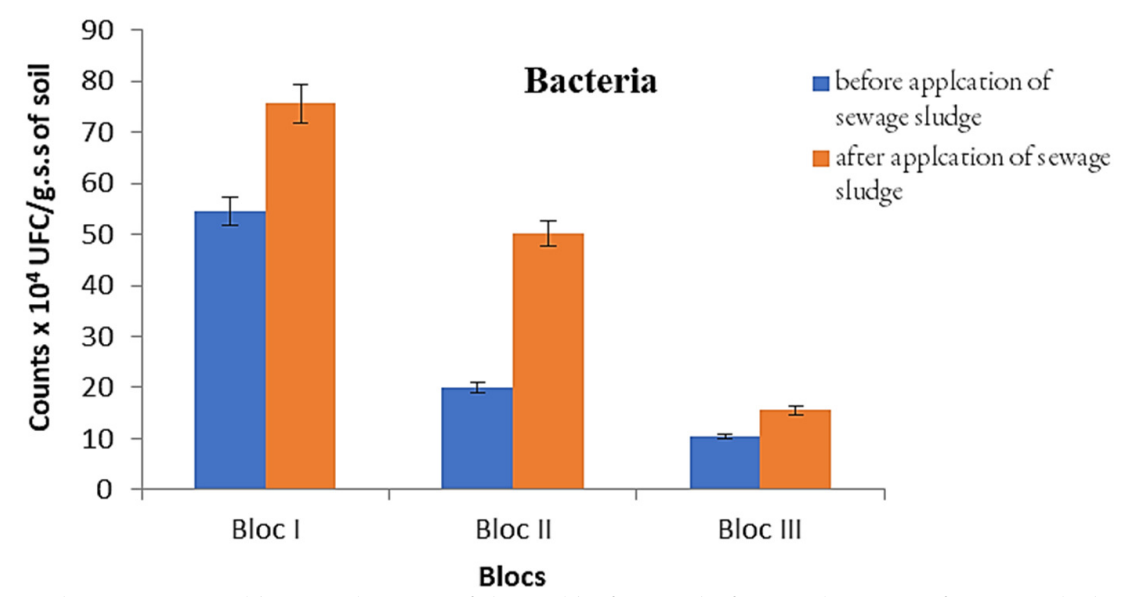

Figure 2. The average total bacterial count of the soil before and after application of Sewage sludge

\section{Total fungi count (TFC)}

Fungi play a role in recycling waste, chemical secretions and excretions from the roots of plants, animals and microorganisms (Zouidi, 2019). The fungal counts in the soil samples before the application of sewage sludge were in the order of $8.78 \times 10^{2} \mathrm{~g} / \mathrm{g}$. s. $s$ and $15.78 \times 10^{2} \mathrm{~g} / \mathrm{g}$. s. s, followed by the values of the total number of mushrooms between $15.20 \times 10^{2} \mathrm{~g} / \mathrm{g}$. s. s and $23.20 \times 10^{2} \mathrm{~g} / \mathrm{g}$. s. $s$ after application of sewage sludge, as shown in Figure 3. Fungi are not the most common soil microorganisms, but their weight is very important due to their large size compared to bacteria (Huber and Schaub, 2011). They are low in our soil due to the alkaline $\mathrm{pH}$ effect because fungi generally support acidic $\mathrm{pH}$; under such conditions, they are more competitive than bacteria for the exploitation of a substrate (Karabi, 2016).

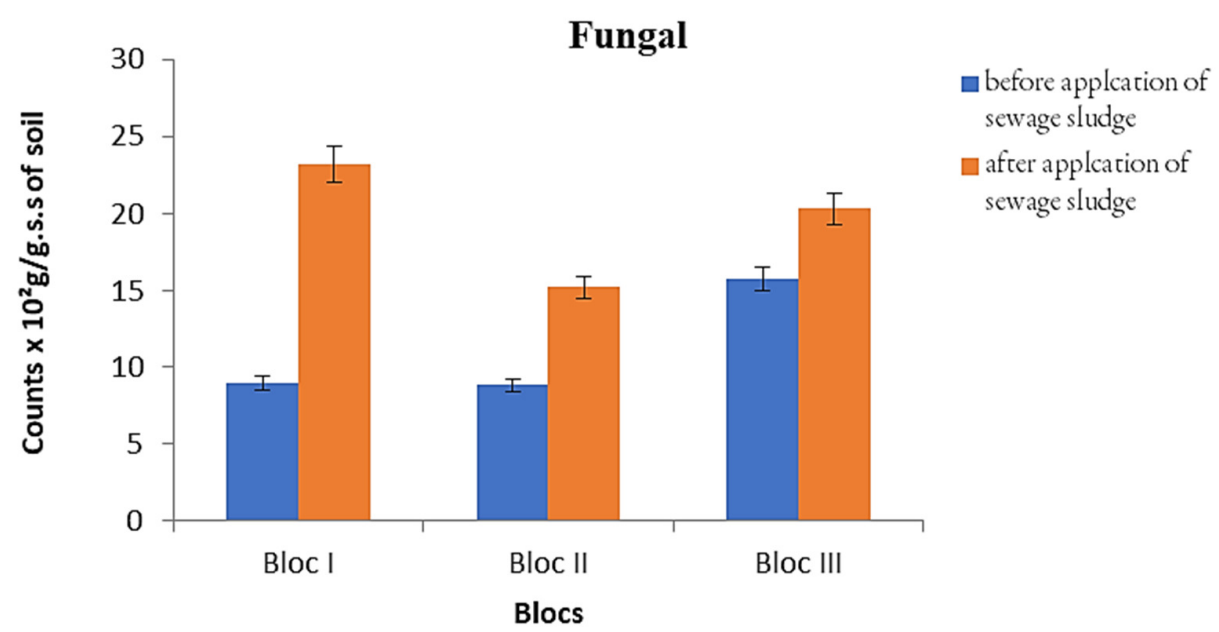

Figure 3. The average total fungi count (TFC) of the soil before and after application of sewage sludge

\section{Total Azotobacter count}

The determination of the Azotobacter showed that are relatively low. The values of the azotobacter varied between $60.45 \times 10^{3} \mathrm{UFC} / \mathrm{g}$ s.s before application of sewage sludge and $90.78 \times 10^{3} \mathrm{UFC} / \mathrm{g}$ s.s after application of sewage sludge (Figure 4). This variation is due to the richness of minerals and organic matter in the soil. This increase of the total aerobic mesophilic flora could be explained by the enrichment of the medium in mineral nitrogen by the aerobic of nitrogen that are also activated after the application of wastewater. 


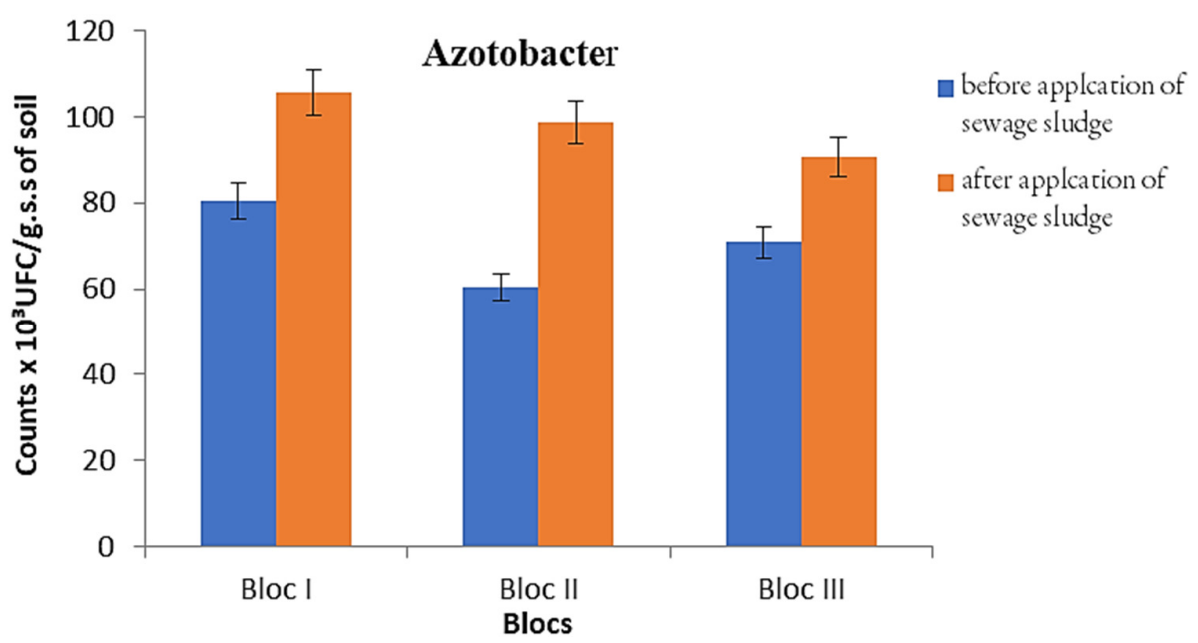

Figure 4. The average of total Azotobacter count of the soil before and after application of sewage sludge

\section{Conclusions}

The application of sewage sludge is a widely used agricultural practice that serves several purposes primarily to improve soil quality. They can also be valued by spreading on agricultural soils. The application makes it possible to recycle part of the sludge and to take advantage of its fertilizing properties since they are rich in organic matter and certain fertilizing elements urban waste are potentially interesting to ensure the biological fertility of soils. Sludge analyses confirm the presence of heavy metals and the various germs which remain below the threshold of international toxicity norms.

The results of this study showed that soil mixed with sewage sludge and fertilizer creates a good support for the physicochemical and biological parameters of agricultural soils in relation to all the treatments used. In physicochemical terms, the greatest impact caused by the application of sludge on the soil was the increased $\mathrm{pH}, \mathrm{EC}$ electrical conductivity, carbon, organic matter and total content of major elements ( $\mathrm{Na}, \mathrm{Mg}, \mathrm{P})$. From a biological point of view this treatment improved the microbial activity mainly by a growth of bacteria, fungi and azotobacter whereas bacteria were the most dominant microorganisms in the soil which can colonize different environmental media by function of variation of temperature, acidity, alkalinity, pressure and salinity.

Finally, the application of sludge changed the physicochemical and biological properties of the soil, so we concluded that the sludge can be used as a natural fertilizer on the soil.

\section{Authors' Contributions}

$\mathrm{DN}, \mathrm{WH}$ and DA designed and performed the experiments and also wrote the manuscript. ZM and MM performed the statistical analysis. ZM and DA reviewed the manuscript. All authors read and approved the final manuscript.

\section{Acknowledgements}

The authors thank to all the members of Research Laboratory "Water, Energy and Environment" (LR3E, code LR99ES35), National School of Engineers of Sfax, BP W, 3038 Sfax, University of Sfax - Tunisia; Ain Defla wastewater treatment plant laboratory; Arzew Oran agronomic analysis laboratory. 


\section{Conflict of Interests}

The authors declare that there are no conflicts of interest related to this article.

\section{References}

Antolín MC, Pascual I, García C, Polo A, Sánchez-Díaz M (2005). Growth, yield and solute content of barley in soils treated with sewage sludge under semiarid Mediterranean conditions. Field Crops Research 94(2-3):224-237. https://doi.org/10.1016/j.fcr.2005.01.009

Becerra-Castro C, Lopes AR, Vaz-Moreira I, Silva EF, Manaia CM, Nunes OC (2015). Wastewater reuse in irrigation: A microbiological perspective on implications in soil fertility and human and environmental health. Environment International 75:117-135. https://doi.org/10.1016/j.envint.2014.11.001

Bedjadj S (2011). Contribution à l'étude des caractéristiques microbiologiques des sols dans la région de Ouargla (Cas de l'exploitation de l'Université de Ouargla) [Contribution to the study of the microbiological characteristics of soils in the Ouargla region (Case of the exploitation of the University of Ouargla)]. University of Ouargla, pp 59. https://dspace.univ-ouargla.dz/jspui/handle/123456789/4561

Benmouffok A, Allili N, Djebala L, Akil A, Medjani A (2005). Caractérisation et valeur agronomique des boues issues d'épuration des eaux usées (cas de la station d'épuration de tizi ouzou Est, Algerie) [Characterization and agronomic value of sludge from wastewater treatment (case of the Tizi Ouzou East treatment plant, Algeria)]. Watmed2 (Marrakech), pp 4.

Boullard B, Moreau R (1962). Sol, microflore et végétation. Equilibres biochimiques et concurrence biologique. [Soil microflora and vegetation. Biochemical equilibria and biological competition]. Masson \& Cie. Paris France, pp 172.

Dommergues Y (1962). Etude de quelques facteurs influant sur le comportement de la microflore du sol au cours de la dessiccation [The effect of some features in the soil microflora during desiccation]. Science du Sol 141-155.

Duchène P (1990). Les systèmes de traitement des boues des stations d'épuration des petites collectivités [Sludge treatment systems from wastewater treatment plants in small communities]. Cemagref Editions, pp 84.

Fernández JM, Plaza C, García-Gil C, Polo A (2009). Biochemical properties and barley yield in a semiarid Mediterranean soil amended with two kinds of sewage sludge. Applied Soil Ecology 42(1):18-24. https://doi.org/10.1016/j.apsoil.2009.01.006

FAO (2015). Agriculture mondiale [Global agriculture]. Horizon 2015/2030 Abridged report http://www.fao.org/3/y3557f/y3557f03.htm

Huber G, Schaub C (2011). La fertilité des sols: L'importance de la matière organique [Soil fertility: the importance of organic matter]. Agriculture and terroir, Bas Rhin chamber of agriculture. Environment-Innovation Department, pp 46.

Karabi M (2016). Fonctionnement microbiologique des sols oasiens. Cas de quelques sols de la region de Ouargla [Microbiological functioning of oasis soils. Case of some soils in the Ouargla region]. Doctoral thesis, University of Ouargla, pp 215. https://dspace.univ-ouargla.dz/jspui/bitstream/.pdf

Kulling D, Stadelmann F, Herter U (2001). Sewage sludge - fertilizer or waste. In: UKWIR Conference, Brussels, pp $9-$ 11.

Morisot A, Tournier JP (1986). Répercussions agronomiques de l'épandage d'effluents et déchets de moulins à huile d'olive. Agronomie [Agronomic repercussions of the spreading of effluents and waste from olive oil mills]. Agronomy 6(3):235-243. https://hal.archives-ouvertes.fr/hal-00884871/document

Mi W, Wu L, Brookes P-C, Liu Y, Zhang X, Yang X (2016). Changes in soil organic carbon fractions under integrated management systems in a low-productivity paddy soil given different organic amendments and chemical fertilizers. Soil and Tillage Research 163(1):64-70. https://doi.org/10.1016/j.still.2016.05.009

Mihalache M, Dumitru M, Gament E, Raducu D (2007). Use of sludge from sewage in agriculture. Ed. Solness, Timisoara.

Mosoarca G, Negrea A (2012). Studies regarding the effects of settling tanks sludge recycling on organic matter concentration from treated water. Journal of Environmental Protection and Ecology 13(1):198-202. http://www.jepe-journal.info/vol-13-no 1/Full.pdf 
Ramdani N (2007). Contribution à l'étude des boues d'épuration urbaines issues du traitement des eaux usées, l'effet sur la fertilité des sols sableux [Contribution to the study of urban sewage sludge from the wastewater treatment, the effect on the fertility of sandy soil]. Magister thesis Oran University, pp 34-35. https://theses.univoran1.dz/document/TH2530.pdf

Raïs MT, Khélil MN, Marzougui N, Sabbahi S (2016). Impact de l'epandage agricole des boues residuaires urbaines sur la qualite microbiologique de trois legumes [Impact of agricultural spreading of urban waste sludge on the microbiological quality of three vegetables]. European Journal of Scientific Research 1:26-36. https://www.researchgate.net/publication/301351640

Sahnoun AY (2019). Contribution à la valorisation des boues des stations d'épuration des eaux usées [Contribution to the recovery of sludge from wastewater treatment plants]. Doctoral thesis, University of Oran USTOMB, pp 209.

Sastre I, Vicente MA, Lobo MC (1996). Influence of the application of sewage sludges on soil microbial activity. Bioresource Technology 57(1):19-23. https://doi.org/10.1016/0960-8524(96)00035-1

Singh A, Agrawal M (2011). Management of heavy metal contaminated soil by using organic and inorganic fertilizers: effect on plant performance. IIOAB Journal 2(1):22-30.

Soulignac V (2000). Epandage de boues urbaines, de déchets industriels et d'effluents d'élevage sur les sols agricolesComparatif réglementaire en octobre 2000 [Spreading of urban sludge, industrial waste and livestock manure on agricultural soils - Regulatory comparison in October 2000]. Ingénieries Eau-Agriculture-Territoires 24(2000): 15 .

Sommers LE (1997). Chemical composition of sewage sludges and analysis of their potential use as fertilizers. Journal of Environmental Quality 6(2):225-232. https://doi.org/10.2134/jeq1977.00472425000600020026x

Tchobanoglous G, Burton F (2003). Wastewater engineering: treatment, disposal and reuse. 4th ed. McGraw-Hill Publishing Company Ltd., New York.

Tsadilas CD, Samaras V, Kazai P, Sgouras J (2002). Fly ash and sewage sludge application on an acid soil and their influence on some soil properties and wheat biomass production. In Proceedings of the $12^{\text {th }}$ ISCO Conference, Beijing, pp 118-123.

World Health Organization (1981). The risk to health of microbes in sewage sludge applied to land. Report on a WHO Working Group, Stevenage, 6-9 January 1981.EURO Reports and Studies. https://www.cabdirect.org/cabdirect/abstract/19822702299

Zouidi M (2019). Vulnérabilités du 'continuum' phyllosphère-litière de Pinus halepensis Mill. Dans la zone aride et semi aride de l'ouest de l'Algérie [Vulnerabilities of the phyllosphere-litter 'continuum' of Pinus halepensis Mill. in the arid and semi arid zone of western Algeria]. Doctoral thesis, University of Saida, Algeria, pp 187.

Zouidi M, Borsali AH, Allam A, Gros R (2019). Quality estimation of the western Algeria forest soils. Malaysian Journal of Soil Science 23:87-98. http://www.msss.com.my/mjss/Full\%20Text/vol23/V23_07.pdf
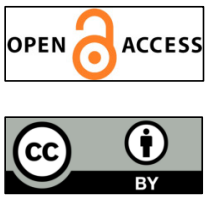

The journal offers free, immediate, and unrestricted access to peer-reviewed research and scholarly work. Users are allowed to read, download, copy, distribute, print, search, or link to the full texts of the articles, or use them for any other lawful purpose, without asking prior permission from the publisher or the author.

License - Articles published in Notulae Scientia Biologicae are Open-Access, distributed under the terms and conditions of the Creative Commons Attribution (CC BY 4.0) License.

(c) Articles by the authors; SHST, Cluj-Napoca, Romania. The journal allows the author(s) to hold the copyright/to retain publishing rights without restriction. 